\title{
Correlation between leptin and LH concentration during peri and postpartum to the onset of estrus postpartum in Bali cattle
}

\author{
D. N. D. I. Laksmi ${ }^{1}$, *, I. G. N. B. Trilaksana ${ }^{1}$, L. M. Sudimartini ${ }^{2}$ and I. W. N. F. Gunawan ${ }^{3}$ \\ ${ }^{1}$ Laboratory of Veterinary Reproduction, Faculty of Veterinary Medicine, \\ Udayana University, Jl. PB Sudirman, Denpasar, Bali 80234 - Indonesia \\ ${ }^{2}$ Laboratory of Veterinary Pharmacology and Pharmacy, Faculty of Veterinary Medicine, \\ Udayana University, Jl. PB Sudirman, Denpasar, Bali 80234 - Indonesia \\ ${ }^{3}$ Laboratory of Veterinary Radiology, Faculty of Veterinary Medicine, \\ Udayana University, Jl. PB Sudirman, Denpasar, Bali 80234 - Indonesia \\ *CorrespondingE-mail: dewiindira@unud.ac.id
}

Received December 16, 2019; Accepted May 28, 2020

\begin{abstract}
ABSTRAK
Mekanisme poros hipotalamus, hipofisis dan ovarium berperan penting pada awal aktivitas luteal postpartum. Penelitian ini bertujuan untuk mengukur kadar hormon leptin, Luteinizing Hormon (LH) saat partum dan saat munculnya estrus pertama postpartum serta melihat munculnya tanda-tanda estrus. Rancangan penelitian yang digunakan adalah observasional prospektif. Sampel yang digunakan adalah sapi Bali pada saat partus dan saat munculnya estrus pertama postpartum yang ada pada beberapa system pertanian terintegrasi (simantri) di Kecamatan Mengwi, Kabupaten Badung, Provinsi Bali. Parameter yang diukur adalah kadar leptin, LH dan waktu munculnya estrus postpartum. Teknik pengukuran kadar hormon dilakukan dengan metode Direct Enzyme-linked immunosorbent assay (ELISA), Double Antibody Sandwich. Hasil penelitian menunjukkan terdapat korelasi antara kadar leptin saat partus dengan waktu munculnya estrus postpartum dengan nilai korelasi $(r)=0,773$. Hasil penelitian menunjukkan bahwa tingginya kadar leptin saat partus waktu munculnya estrus postpartum yang lebih cepat. Namun diperlukan tingkat minimum dari kadar leptin untuk meningkatkan kadar LH sehingga meningkatkan ekspresi munculnya estrus.
\end{abstract}

Kata kunci : Leptin peripartum, LH, estrus postpartum

\begin{abstract}
The mechanism of the hypothalamus, pituitary, and ovaria is important in the early postpartum luteal activity. This study aims to measure levels of the leptin hormone, Luteinizing Hormone (LH) during the first-time postpartum estrus appears and to observe the signs of estrus. The study uses a prospective observational method. The samples were Bali cattle on peripartum condition-while postpartum estrus appeared from several sistem pertanian terintegrasi (Simantri) in Mengwi District, Badung Regency, Bali, Indonesia. The measured parameters were leptin levels, LH, and the onset of postpartum estrus. The technique of measuring hormone levels with the Direct Elisa method and Double Antibody Sandwich. The results showed there were a positive correlation $(\mathrm{r}=0.773)$ between leptin levels at peripartum and the onset of postpartum estrus. The higher level of leptin, the faster of postpartum estrus appears. However, a minimum leptin value is needed to increase the LH level so that
\end{abstract}


expression of estrus appearance is clearly.

Keywords: peripartum Leptin, LH, postpartum estrus

\section{INTRODUCTION}

In Indonesia, particularly in Bali island, Bali cattle has potential as an important source of animal protein to fulfill daily protein requirements. This is due to the high productivity of Bali cattle. As livestock with many benefits, Bali cattle help farmers working in their fields.

Many factors affect reproduction such as Service per Conception (S/C), Calving Interval (CI) and Body Condition Score (BCS) (Senger, 2002; Hudson, 2011). Laksmi et al. (2018) reported BCS and hormone of postpartum anestrus Bali cattle was closely related. The calving rates of Bali cattle is low. The impaired reproductive function can result in the reduction of calving rates. According to Kamal et al. (2014), the economy value of livestock breeding generally depends on the successful of creating optimal calving interval. The postpartum anestrus period must be maintained within 65 days (Kamal et al., 2014).

Olsen (2009) reported that energy balance strongly influences the duration of postpartum anestrus. The low nutrient intake prior to or following parturition will increase the time interval between parturition to the onset of the subsequent estrus cycle. Once a negative energy equilibrium following parturation is achieved, the remaining energy reserve shall be restored in adipose tissue. Agarwal et al. (2009) reported that leptin is a hormone released by adipose tissue. This hormone has a molecular weight of $16 \mathrm{kDa}$ and consists of no less than 146 amino acids that play a role in delivering of hypothalamicpituitary-ovarian axis metabolism

Kadokawa et al. (2000) stated that in the early postpartum period, leptin concentration decreases until reaching its lowest concentration and rises back to stimulate the hypothalamus for releasing Gonadotropin-releasing hormone $(\mathrm{GnRH})$. In addition, the longer the interval between parturition and the lowest leptin concentration will prolong the onset of estrus and the first ovulation after calving. While Liefers (2004) reported that animals show higher leptin concentration tend to demonstrate better estrus.

Leptin is one of the metabolic signals which has fuction of regulating the hypothalamushypophysis-ovarian axis (Zieba et al., 2003;
Ahmadzadeh et al., 2011). Highly sensitive hypothalamus in response to specific leptin concentration is required before the activation of GnRH neurons and being able to stimulate the secretion of gonadotropin. Nutrition can also have direct effects both on the hypothalamus by synthesizing and releasing GnRH and on the anterior hypophysis by controlling the synthesis and secretion of Follicle-stimulating hormone (FSH), LH, and Growth hormone (GH) (Diskin et al., 2003).

Although the currently available evidence has defined the leptin concentration during lactation in dairy cows (Kadokawa et al., 2000; Block et al., 2001), however, there is no single study investigating the correlation between peripartum leptin concentration and the onset of the first postpartum estrus in Bali cattle. This study expected that by investigating the correlation of it can increase efficiency of reproductive function by delivering one calf in a year or achieving the one-year calving interval.

\section{MATERIALS AND METHODS}

\section{Materials}

The study used 38 heads of Bali cattle which were in peripartum period and during the first onset of postpartum estrus. The samples were pluripara cattle that already gave birth more than once and do not show any signs of illness. The cattle were raised in a stall system. The cattle were fed with King grass $(25 \mathrm{~kg})$ and concentrate of commercial feeding $(2 \mathrm{~kg})$ with the nutritional content consisting of: water $12 \%$, crude protein $12 \%$, fat $4 \%$, crude fiber $17-20 \%$, ash $10 \%$, Total Digestible Nutrient $>64 \%$ minimum, Calcium 0.9$1.2 \%$ and Phosphorus $0.6-0.8 \%$. The grass was given twice a day at $10 \mathrm{am}$ and $4 \mathrm{pm}$. While the concentrate food was given at $8 \mathrm{am}$.

The instruments used in this study included vacutainer tube, $18 \mathrm{G}$ needle, needle holder, washer 420 biomeriex, ELISA reader 470 biomeriux, incubator $37{ }^{\circ} \mathrm{C}, 10-100 \mu \mathrm{L}$ adjustable pipette, $20-200 \mu \mathrm{L}$ adjustable pipette, $1000 \mu \mathrm{L}$ fixed pipette, and printer. The materials used in this study included Bovine serum, Bovine LEP Elisa KIT (Lot. 201307), and Bovine LH Elisa KIT. 


\section{Methods}

This study was a prospective observational study where the collection of independent variable data (cause) done before the collection of dependent variables (outcome). Blood samples were collected through jugular vein puncture. The blood was collected in an anticoagulant-free container, incubated at room temperature for 15 minutes, and was subsequently centrifuged at $3000-4000 \mathrm{rpm}$ for $15-20$ minutes to obtain the serum. The obtained serum was stored at $-20{ }^{\circ} \mathrm{C}$ until the measurement of leptin and LH concentration was measured. Hormone concentration was measured using Direct Elisa, Double Antibody Sandwich method.

Estrus observation of postpartum cattle was performed twice a day in the morning (06.0009.00 AM) and in the evening (04.00-06.00 PM). Signs of estrus were observed including restlessness, vagina swelling, and erythema of vulva covered by transparent mucus, increased blood flow to vaginal mucus, urination, rising tail indicating that the cattle were ready for mating (Hafez and Hafez, 2000).

\section{Data Analyses}

The analyses of correlation and regression were performed in order to assess for the correlation and adherence between leptin concentration and the occurrence of the first onset of postpartum estrus.

\section{RESULTS AND DISCUSSION}

Correlation between peripartum and postpartum leptin concentration is presented in Figure 1 with the following regression equation: $\mathrm{Y}=0.676 \mathrm{X}+-1.061$. Where $\mathrm{Y}$ is peripartum leptin and $\mathrm{X}$ is postpartum estrus leptin concentration. The coefficient of determination $\left(\mathrm{R}^{2}\right)$ of $88.1 \%$ indicates that peripartum leptin concentration contributes to $88.1 \%$ of leptin concentration during postpartum estrus period or $88.1 \%$ of leptin concentration during postpartum estrus period is influenced by peripartum leptin concentration and the remaining $11.9 \%$ is influenced by other factors. The value or correlation coefficient (R) of 0.939 (very close) indicates that peripartum leptin concentration is closely correlated with leptin concentration during the postpartum estrus period.

In ruminants, the concentration of circulating leptin is positively correlated with body fat accumulation, but this correlation perhaps only explains around $10-30 \%$ of the variation in leptin concentration. This phenomenon means that other factors play more important roles in this regard, one of which is food intake. Hence, leptin secretion is regulated in the short, medium, and long term by food intake, nutrition, and hormones (Kadokawa et al., 2000).

Peripartum leptin concentration was lower than postpartum leptin concentration (Table 1). Kadokawa et al. (2000) stated that leptin concentration decreases after birth. After reaching the lowest concentration, the concentration begins to rise and becomes stable at the first ovulation during postpartum period. Thus, the delay in the first ovulation correlates with birth to lowest leptin interval.

Leptin concentration is high during the late of pregnancy period, and it progressively decreases towards the basal levels after birth in sheep and cattle (Kadokawa et al., 2000). Furthermore, due to the lack of long-form leptin receptors in the hypothalamus (Garcia et al., 2000), there is a little signal to reduce food intake. On the other hand, there is an increase in leptin soluble binding protein during pregnancy (Liefers, 2004).

High leptin concentration during pregnancy is a result of the high energy required for the upcoming lactation period. Food intake affects the production of leptin during the lactation period. Higher food intake is linked to higher leptin concentration. In normal, non-pregnant, nonlactating sheep and cattle and those with higher energy levels demonstrate higher leptin concentration (Delavaud et al., 2000; Chilliard et al., 2001; Delavaud et al., 2002). Buyse et al. (2001) reported that higher food intake results in higher insulin concentration and affects leptin production by the adipose tissue.

A positive or negative energy balance during lactation affects leptin concentration. During lactation period, cows that have a positive energy balance show higher leptin concentration compared to those with negative energy balance. Cattle with positive energy balance have higher food intake and body weight compared to those with negative energy balance. These findings were confirmed by studies that linked between energy balance and leptin concentration (Block et al., 2001, Reist et al., 2003).

Cattle in positive energy balance condition show less fat mobilization. This motion indicates the return of leptin concentration after birth. However, cattle with negative energy balance will 


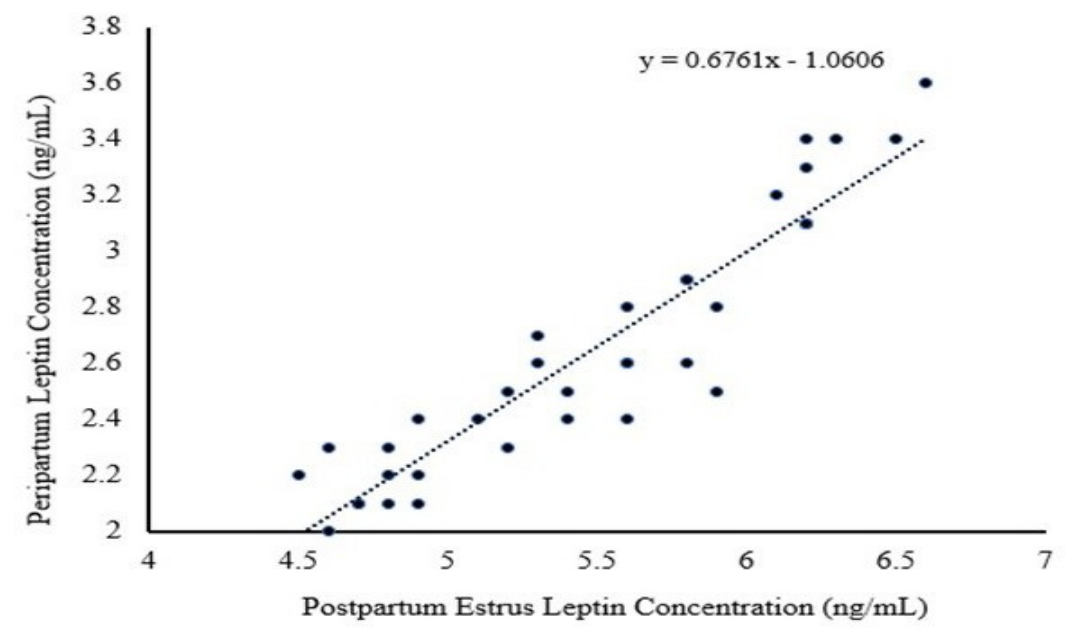

Figure 1. Correlation between Peripartum Postpartum estrus of Leptin Concentration. $\bullet$ : observed; -: estimated

Table 1. Mean $(x \pm \mathrm{SD})$ Leptin and LH Concentration in Bali Cattle

\begin{tabular}{rcc}
\hline Hormone & Peripartum & Postpartum estrus \\
\hline Leptin $(\mathrm{ng} / \mathrm{mL})$, & $2.60 \pm 0.47$ & $5.42 \pm 0.47$ \\
LH $(\mathrm{ng} / \mathrm{mL})$, & $2.43 \pm 0.39$ & $5.55 \pm 0.37$ \\
\hline
\end{tabular}

reach leptin concentration below the lowest concentration at birth. The return of leptin concentration after birth seems to depend on the amount of fat deposition (Liefers, 2004).

\section{Correlation between Peripartum Leptin Concentration and Postpartum Estrus LH Levels}

Statistical analysis of the correlation between peripartum leptin concentration and postpartum estrus LH levels resulted in a correlation coefficient $(r)=0.907$ and a coefficient of determination $(\mathrm{r} 2)=0.822$ with a regression line equation $\mathrm{y}=3.688+0.713 \mathrm{x}$, where $\mathrm{Y}$ is postpartum LH hormone levels and $\mathrm{X}$ is peripartum leptin hormone levels (Figure 2).

Figure 2 shows that peripartum leptin concentration was closely related to LH hormone levels and contributes to around $82.2 \%$ of the $\mathrm{LH}$ hormone levels. Leptin is a cytokine hormone secreted mainly by adipose tissue, which acts as a direct metabolic signal to the central nervous system and controls the release of LH (Agarwal et al., 2009). Frequency of LH pulses was correlated positively with energy balance $(r=0.51)$ and plasma leptin concentrations $(r=0.73)$. Amplitude of the LH pulses was correlated only with leptin ( $\mathrm{r}$ $=0.53$ ). First ovulation was observed $34 \pm 4 \mathrm{~d}$ after parturition. These observations reveal an important linkage between pulsatile LH secretion and blood leptin concentrations during the early postpartum period in dairy cows, when their energy balance is negative, and may explain the delay in ovulation. (Kadokawa et al., 2000). Between leptin production and the reproductive axis seems to be a strong physiological relationship. Colakoglu et al. (2017) reported that there is a significant correlation between leptin levels and the initiation of ovarian activity after parturition. Kadokawa et al. (2000), found that the pulsatile frequency of LH was positively correlated with energy balance. Leptin levels also correlate with pulsatile LH amplitude. According to Leifer (2004), a certain concentration of leptin 


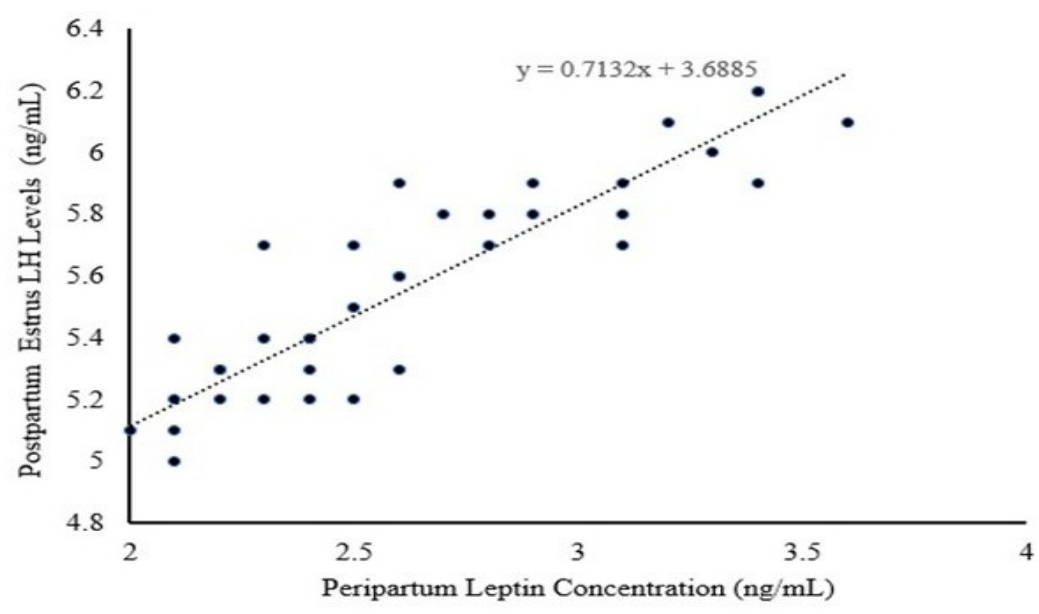

Figure 2. Correlation between Peripartum Leptin and Postpartum Estrus LH Concentration in Bali Cattle . •: observed; -: estimated

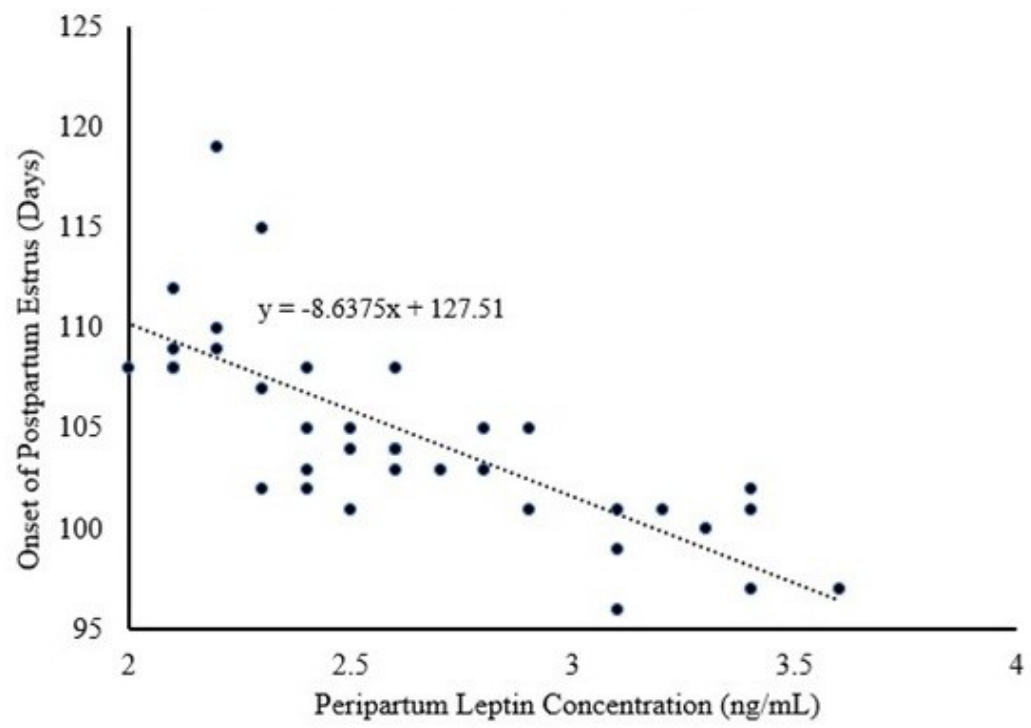

Figure 3. Correlation between Peripartum Leptin Concentration and the Onset of Postpartum Estrus in Bali Cattle. •: observed; -: estimated

is required to trigger $\mathrm{LH}$ secretion for ovulation.

Other studies suggest that low leptin concentration during the early postpartum and pulsatile LH periods tends to be inhibited because various neurotransmitters, such as opioids, suppress the neuronal activity of GnRH. This indicates a direct relationship between LH pulsatile release and leptin concentration in dairy cattle during the postpartum period before the first ovulation (Kadokawa et al., 2000).

\section{Correlation between Peripartum Leptin Concentration and the Onset of Postpartum Estrus}

Statistical analysis of the correlation between peripartum leptin concentration with the onset of postpartum estrus gives resulted in a correlation coefficient $(r)=0.773$ and a coefficient of determination $(\mathrm{r} 2)=0.598$ with a regression line equation $\mathrm{y}=-8.638+127.507 \mathrm{x}$, where $\mathrm{Y}$ is the onset of postpartum estrus and $\mathrm{X}$ is the peripartum leptin concentration (Figure 3). 
The value of closeness or correlation coefficient (r) of 0.773 (very close) indicates that the concentration of peripartum leptin is closely correlated with the onset of postpartum estrus. Figure 3 shows that the higher of peripartum leptin concentration the faster of onset postpartum estrus, and vice versa. According to Laksmi (2016), administration of leptin at a dose of 100 $\mu \mathrm{g} / \mathrm{mL}$ caused the emergence of estrus at an average of $57.33 \pm 5.29$ hours following administration. Whereas at a dose of $200 \mu \mathrm{g} / \mathrm{mL}$, the estrus seems to occur at an average of $49.33 \pm$ 4.00 hours after administration. This shows that the administration of $200 \mathrm{mg} / \mathrm{mL}$ dose of leptin causes the emergence of postpartum estrus faster than the administration of $100 \mathrm{mg} / \mathrm{mL}$ of leptin. This evidence prove that leptin dose is important to achieve an increase of LH concentration (Zieba et al., 2003).

Normally, postpartum estrus occurs after uterine involution, defined as the return of uterine function and reproductive organs. According to Hafez and Hafez (2000), the duration of uterine involution in cattle ranges from 30-60 days. Postpartum estrus is important for achieving yearly delivery with a birth interval of 365 days. Socheh et al. (2017) stated the factors that accelerate the emergence of post-partum estrus include weaning age. The early weaning age of 105 days results in a faster postpartum estrus and higher estrus intensity. At 205 days of weaning showed that the onset of postpartum estrus occurs two days later.

\section{CONCLUSION}

Bali cattle leptin hormone levels during peripartum will decline to $2.60 \mathrm{ng} / \mathrm{mL}$ and increase slowly to $5.42 \mathrm{ng} / \mathrm{mL}$. The higher level of peripartum leptin, the faster of postpartum estrus appearance times.

\section{ACKNOWLEDGEMENTS}

The author would like to thank the Udayana University for the research grant no. 0798/UN14.2.9/LT/2018, year of funding of 2018 so that this research can be completed as expected

\section{REFERENCES}

Agarwal, R., P.K. Rout and S.K. Singh. 2009. Leptin: A Biomolecule for Enhancing Livestock Productivity. Indian J. Biotechnol.
8(2):169-176.

Ahmadzadeh, A., K. Carnahan, and C. Autran. 2011. Understanding Puberty and Postpartum Anestrus. Proceeding, Applied Reproductive Strategies in Beef Cattle September 30 - October 1, 2011; Boise, ID.

Block, S. S., W. R. Butler, R. A. Ehrhardt, A. W. Bell, M. E. van Amburgh, and Y. R. Boisclair. 2001. Decreased concentration of plasma leptin in periparturient dairy cows is caused by negative energy balance. Endocrinol. 171(2):339-348.

Buyse, M., S. Viengchareun, A. Bado, and M. Lombes. 2001. Insulin and glucocorticoids differentially regulate leptin transcription and secretion in brown adipocytes. The FASEB Journal. 15(8):1357-1366.

Colakoglu, H.E., I.M. Polat, M.R. Vural, S. Kuplulu, M. Pekcan, M.O. Yazlik, and C. Baklac. 2017. Associations between Leptin, body condition score, and energy metabolites in Holstein primiparous and multiparous cows from 2 to 8 weeks postpartum. Revue. Med. Vet. 168(4-6): 93101.

Chilliard, Y., M. Bonnet, C. Delavaud, Y. Faulconnier, C. Leroux, J. Djiane, and F. Bocquier. 2001. Leptin in ruminants. Gene expression in adipose tissue and mammary gland, and regulation of plasma concentration. Domest. Anim. Endocrinol. 21(4):271-295.

Diskin, M.G., D.R. Mackey, J.F. Roche, and J.M Sreenan. 2003. Effects of Nutrition and Metabolic Status on Circulating Hormones and Ovarian Follicle Development in Cattle. Anim. Reprod. Sci. 78(3-4):345-370.

Delavaud, C., F. Bocquier, Y. Chilliard, D. H. Keisler, A. Gertler, and G. Kann. 2000. Plasma leptin determination in ruminants: effect of nutritional status and body fatness on plasma leptin concentration assessed by a specific RIA in sheep. Endocrinol. 165(2):519-526.

Delavaud, C., A. Ferlay, Y. Falconnier, F. Bocquier, G. Kann, and Y. Chilliard. 2002. Plasma leptin concentration in adult cattle: Effect of breed, adiposity, feeding level, and meal intake. Anim. Sci. 80(5):1317-1328.

Garcia, M. D., F. F. Casanueva, C. Dieguez, and R. M. Senaris. 2000. Gestational profile of leptin messenger ribonucleic acid (mRNA) content in the placenta and adipose tissue in the rat, and regulation of the mRNA levels 
of the leptin receptor subtypes in the hypothalamus during pregnancy and lactation. Biol. Reprod. 62(3):698-703.

Hafez, E.S.E. and B. Hafez. 2000. Reproduction in Farm Animals. $7^{\text {th }}$ Ed. Lippincott William \& Wilkins. A Wolters Kluwer Company.

Hudson, C. 2011. Understanding the factors affecting dairy cow fertility. BMJ. Vet. Rec. 168(11): 299-300.

Kadokawa, H., D. Blache, Y. Yamada and G.B. Martin. 2000. Relationships Between Changes in Plasma Concentrations of Leptin Before and After Parturition and the Timing of First Post-partum Ovulation in Highproducing Holstein Dairy Cows. Reprod. Fertil. Dev. 12(7-8):405-411.

Kamal, M.M., M.M.U. Bhuiyan, N. Parveen, H.W. Momont and M. Shamsuddin. 2014. Risk Factors for Postpartum Anestrus in Crossbred Cows in Bangladesh. Turk. J. Vet. Anim. Sci. 38(2):151-156.

Laksmi, I., T. Pemayun, I. Damriyasa and N. Dharmawan. 2016. Administration of Leptin Increases the Level of Follicle Stimulating Hormone (FSH) and Development of Ovarian Follicles in Postpartum Anestrus of Bali Cattle. Bali Medical Journal. 5(2):6973.

Laksmi, D. N. D. I., I.G.N.B. Trilaksana, R.J. Darmanta, M. Darwan, I.W. Bebas and K.K. Agustina, K. K. 2018. Correlation between body condition score and hormone level of Bali cattle with postpartum anestrus. Indian J. Anim. Res., 53(12):15991603

Liefers, S. 2004. Physiology and Genetics of Leptin in Periparturient Dairy Cows. (Ph.D. Thesis). Animal Breeding and Genetics,
Wageningen University, Wageningen and Division of Animal Resources Development, Animal Sciences Group, Lelystad.

Olsen, J.R. 2009. Changes in Temporal Leptin Concentrations and Other Metabolic Factors in Primiparous, Postpartum, Anestrous, Suckled, Beef Cows. (Thesis). Animal and Range Sciences. Montana State University. Bozeman, Montana.

Reist, M., D. Erdin, D. Von Euw, K. Tschumperlin, H. Leuenberger, C. Delavaud, Y. Chilliard, H. M. Hammon, N. Kunzi and J. W. Blum. 2003. Concentrate feeding strategy in lactating dairy cows: metabolic and endocrine changes with emphasis on leptin. J. Dairy Sci. 86(5):1690-1706.

Senger, P. L. (2002). Fertility factors-which ones are really important. Proceedings of the American Association of Bovine Practitioners. 35:112-123.

Socheh, M., D.M. Saleh, dan Widiawati. 2017. Postpartum Heat Dan Intensitas Estrus Induk Sapi Brahman Berbasis Penyapihan Umur Pedet Yang Berbeda. Prosiding Seminar Teknologi dan Agribisnis Peternakan V: Teknologi dan Agribisnis Peternakan untuk Mendukung Ketahanan Pangan, Fakultas Peternakan Universitas Jenderal Soedirman , 18 November 2017, P. 102-107.

Zieba, D. A., M. Amstalden, S. Morton, J.L. Gallino, J.F. Edwards, P.G. Harms and G.L. Williams. 2003. Effects of leptin on basal and GHRH-Stimulated GH secretion from the bovine adenohypophysis are dependent upon nutritional status. J. Endocrinol. 178(1):83-90. 